\title{
45. COMPOSITION OF BASALTIC ROCKS RECOVERED AT SITES 367 AND 368, DEEP SEA DRILLING PROJECT, NEAR THE CAPE VERDE ISLANDS
}

\author{
J. Natland, Scripps Institution of Oceanography, La Jolla, California
}

Basalts were recovered at Sites 367 and 368 on Leg 41. Site 367 is southeast of the Cape Verde Islands in the magnetic quiet zone on what appears to be oceanic crust. Over 1000 meters of sediment, the oldest of which is Middle to Upper Jurassic in age, overlie an extrusive basalt sequence with the characteristics of lavas erupted under water. Glass and glass-breccia zones, the principal criteria for identifying pillow lavas among drilled basalts, are abundant. Duncan and Jackson (this volume) report a minimum radiometric age of 110 million years on one sample of these basalts. This date, they feel, does not preclude the Jurassic basement age determined by biostratigraphic methods (Chapter 3, this volume).

Drilling at Site 368 on the Cape Verde Rise northeast of the islands penetrated two thin $(\sim 20 \mathrm{~cm})$ and one fairly thick $(14 \mathrm{~m})$ basalt units within 20 meters of drilled section. These units intrude Turonian-Albian black shales. Bleaching and recrystallization of the sediments both above and below the thickest of these units is interpreted to reflect baking of the sediments following intrusion (Chapter 4, this volume). This intrusive unit, which was almost completely recovered, has a coarse-grained subophitic or "diabasic" texture through most of its interior, suggesting slower cooling rates than are typical of sea-floor basalts, but which can occur in dikes or sills. The lateral continuity of the "basalt" reflector in the vicinity of Site 368 on airgun records indicates that the basalts are horizontal sills rather than vertical or oblique plugs or dikes, although plug-like features rise from this regional reflector elsewhere (see Chapter 4, this volume). The intrusive character of the basalts is confirmed by concordant $\mathrm{K} / \mathrm{Ar}$ whole-rock and ${ }^{40} \mathrm{Ar} /{ }^{39} \mathrm{Ar}$ incremental heating ages of 19 million years (early Miocene) reported by Duncan and Jackson (this volume).

This paper presents X-ray fluorescence and atomic absorption chemical analyses of basalt samples from the two sites. The data were obtained to determine the petrologic character of potential oceanic crustal rocks of Jurassic age at Site 367, and of the Miocene intrusive rocks at Site 368, which may mark the initial stages of Cape Verde Island volcanism, and may be associated with the uplift of the Cape Verde Rise.

\section{BASALT DESCRIPTIONS}

\section{Site 367, Cores 38-40}

Basalts at Site 367 are moderately to intensely altered fine-grained to glassy aphyric or sparsely plagioclaseand olivine-phyric pillow lavas and flows. Several glassy zones, including glass breccias, occur in the cores. Grain size differences and glass or glass breccia zones define at least 13 cooling units, the thickest of which is 1.6 meters. This is the very topmost flow or pillow recovered (see Table 1). Recovery of basalt in Core 38 approaches $100 \%$, and was about $90 \%$ in the short Cores 39 and 40 (2-3 m penetration each). Therefore the average cooling unit size below the topmost flow is $45 \mathrm{~cm}$, with a minimum thickness of $5 \mathrm{~cm}$.

The basalts have been pervasively altered to olivegreen, gray-green, or green-brown colors, reflecting the relative importance of green smectites and reddish hydrous iron oxides. The reddish zones are concentrated near cracks in coarser grained material, whereas the dark green zones are close to the very finegrained and glassy portions of the rocks. Alteration is most intense near cooling unit boundaries, which apparently originally were separated by a few centimeters of void space. These voids are now filled with numerous $1-10 \mathrm{~mm}$ glass fragments spalled from the surfaces of the quenched and cracked molten pillows all cemented by calcite. Calcite is also present in veins or cracks which range from $1 \mathrm{~mm}$ to $3 \mathrm{~cm}$ thick. Reddish clays and/or hydrous iron oxides line some of these veins, either along the edges or in the center of the calcite veins. Reddish sediments overlie the basalts; these may be related to the solutions which deposited ferruginous components in the veins. Calcite, green clays, and ferruginous material also fill vesicles and vugs in the basalts, attesting to the permeability of these fine-grained rocks. Pyrite associated with calcite lines vesicles in Section 38-2, suggesting small-scale variability in oxidation potential, $p \mathrm{H}$, or both, or possibly fluctuations in Eh and $p \mathrm{H}$ during diagenesis.

Thin sections supplied to the author by the shipboard party are of basalt pieces from very near the edges of pillows. The textures are spherulitic, with interlocking sworls of skeletal plagioclase needles. Between the plagioclase needles are thin zones of altered glass and fine clinopyroxene crystallites. In reflected light, the thin sections have an orange cast from extensive oxidation of titanomagnetite and/or glass. In transmitted light, the altered glass has a dull green appearance, indicative of smectites. Very rare microphenocrysts of plagioclase and altered skeletal olivine are present. The olivine can be identified by crystal outline only, as it has been entirely replaced by clays.

The samples analyzed from Site 367 are fragments of the samples used by Duncan and Jackson (this volume) for radiometric age determinations. The samples corrtained abundant smectites, but were slightly coarser grained than the pieces from which the thin sections were made; overall they were probably considerably 
TABLE 1

Descriptive Notes Cores 38-40, Site 367

Sample $38-185 \mathrm{~cm}$ to $38-2,16 \mathrm{~cm}$

Light brownish gray probable Fe- and Mn-rich sediments. Green colored 1-109-112 and 2-1-17.

Sample 38-2, 16-150 cm (Core 38: $100 \%$ [?] basalt recovered)

Upper part of cooling unit extending to Section $3,33 \mathrm{~cm}$.

Fine-grained to very fine grained dark green-black aphyric basalt.

A calcite-cemented "fracture" breccia occurs at $30-35 \mathrm{~cm}$, and calcite veins at 106 and $136 \mathrm{~cm}$. Calcite fills vesicles forming small white dots every few centimeters in the lower part of the section. A large calcite vug occurs at $148-150 \mathrm{~cm}$. Greenish color due to alteration to smectites.

Section 38-3

Fine-grained to very fine grained, locally glassy, moderately to intensely altered aphyric basalt. Coarser grained basalt with "felty" skeletal plagioclase mosaic texture from 3-70 to 3-100. Probable cooling unit boundaries are as follows:

$33 \mathrm{~cm}$ : a calcite-filled cavity with intensely altered greenish glassy fragments. A possible basalt "xenolith" as included in basalt from $20-28 \mathrm{~cm}$.

$100-115 \mathrm{~cm}$ : Breccia zone cemented by calcite with abundant altered basalt glass (?) fragments and one large angular clast.

120-130 cm: A piece of finer grained basalt than that either above or below, but no glass is on the piece.

Alteration is most intense in the calcite-cemented breccia zones. Calcite veins are fairly abundant, some near $55-65 \mathrm{~cm}$ lined additionally with reddish smectites and/or hydrous iron oxides. A prominent calcite vein occurs at $133-137 \mathrm{~cm}$.

Sample 39-1, 50-150 cm (Core 39: 87\% recovered)

Fine-grained, very fine grained to glassy moderately to intensely altered greenish black basalt.

Calcite-cemented altered basalt breccia zones $80-89 \mathrm{~cm}, 100-103$ $\mathrm{cm}$, and $122-133 \mathrm{~cm}$. The second of these is a probable cooling unit transition. A chert inclusion (?) occurs at $117-120 \mathrm{~cm}$. Calcite veins and small $(1 \mathrm{~mm})$ calcite-or smectite-filled vesicles are common.

Sample 39-2, 1-150

Aphyric fine-grained to glassy greenish gray or greenish brown moderately to intensely altered basalt. Cooling unit boundaries (fine grained or glassy) at $27-28 \mathrm{~cm}, 36-38 \mathrm{~cm}, 66-68 \mathrm{~cm}$, and $124-126 \mathrm{~cm}$. A calcite cemented breccia zone with basalt fragments and a fine-grained matrix (formerly fine glass?) altered to green smectites. Between 107 and $111 \mathrm{~cm}$ may also be a cooling unit boundary.

Sample 40-1, 1-150 cm (Core 40: 67\% recovered)

Basalt similar to Core 39 . Probable cooling unit boundaries $86-88 \mathrm{~cm}, 144-146 \mathrm{~cm}$. Amygdular calcite and smectites fill vesicles below $108 \mathrm{~cm}$.

less altered. No thin sections were made from them because all the material was required for first radiometric, then chemical analyses.

\section{Site 368, Cores 60-62}

The intrusive basalts of Site 368 include two small presumed sills in Core 60, Sections 1 and 4, and one fairly thick massive sill intersected from Core 60 , Section 5, to Core 62, Section 2. Black shales occur above and below all three units, and are bleached both above and below the thickest unit, apparently as a result of baking of the sediments during intrusion.

The basalts are dark gray to greenish gray. The two thin units and the top and bottom of the thick unit are very fine grained, aphyric, non-vesicular basalts. Thin sections of the topmost unit and of the margins of the massive unit reveal extremely fine grained-but not glassy-aphanitic basalts consisting of a mosaic of tiny interlocking skeletal plagioclase and clinopyroxene crystals. These crystals form at least $60 \%$ of each section. Olivine is absent. Pale olive-green secondary clays, presumably replacing glass, occur throughout the crystalline mosaic, accounting for the remaining $40 \%$. The clays are associated with abundant fine-grained calcite and (seen in reflected light) a fine dusting of pyrite. Alteration thus appears to have involved dissolution and leaching of the glass, partial conversion of the remaining components to clays, and filling of the space made available by dissolution with calcite and pyrite. Sulfur for the latter was obviously derived from the adjacent carbonaceous sediments.

The interior of the thick basalt unit is much coarser grained than its margins, becoming so within only about $20 \mathrm{~cm}$ of the edge of the unit, further evidence that the basalt is intrusive. The grain size in the interior approaches $5 \mathrm{~mm}$ with subophitic texture predominating (Figure 1). Here the rock is about $90 \%$ crystallized with large euhedral labradorite crystals poikilitically enclosed by pale brown subhedral diopsidic augite or augite $\left(2 \mathrm{~V}^{-}\right.$about $\left.55^{\circ}\right)$. Some clinopyroxene exhibits a skeletal or dendritic morphology, especially at the edges of crystals adjacent to feldspars. This may reflect increasing viscosity of residual liquids as temperatures dropped, and crystal growth was inhibited. Primary titanomagnetite is scattered throughout the sections, by pyrite is the most abundant opaque in the basalts, amounting to over $2 \%$ in the mode. It is invariably associated with altered glass and clays. The sulfides are arranged in subparallel rows along the principal cleavage plates of the clays (Figure 2 ). The clays are clear or pale olive-gray, and can be distinguished from minor intergranular green chlorite which has formed at the expense of flakes of late-stage magmatic or deuteric biotite. The biotite is very sparse and only occurs in the coarsest grained interior portions of the thick basalt unit.

Even in the interior of the thick sill, a small amount of calcite and pyrite (1\%-2\%) fills voids created by the formation of vesicles as crystallization proceeded (the fine-grained margins are non-vesicular) or as alteration occurred. The calcite and secondary clays both replace intersertal glass.

\section{CHEMICAL COMPOSITION OF THE BASALTS}

Major and trace element data for basalts from Sites 367 and 368 are listed in Table 2 along with norms computed dry, reduced, and normalized to $100 \%$, and norms computed dry, partially oxidized $\left(1.5 \% \mathrm{Fe}_{2} \mathrm{O}_{3}\right)$, and normalized to $100 \%$. The analyses were determined by X-ray fluorescence and atomic absorption techniques described by Clague (1974). Powders were first dried at $110^{\circ} \mathrm{C}$; the analyses are thus moisture free. For each element, the data were fitted to least-squares lines for a variety of international geochemical reference standards. Trace elements $\mathrm{Zr}$ and $\mathrm{Ba}$, determined by X-ray fluorescence, were corrected for matrix effects; $\mathrm{Zr}$ was corrected for $\mathrm{Sr}$ interference.

The difference in the totals of the analyses from $100 \%$ reflects primarily the presence of combined water $\left(\mathrm{H}_{2} \mathrm{O}^{+}\right)$and $\mathrm{CO}_{2}$ plus the conversion of $\mathrm{Fe}_{2} \mathrm{O}_{3}$ to $\mathrm{FeO}^{*}$ 


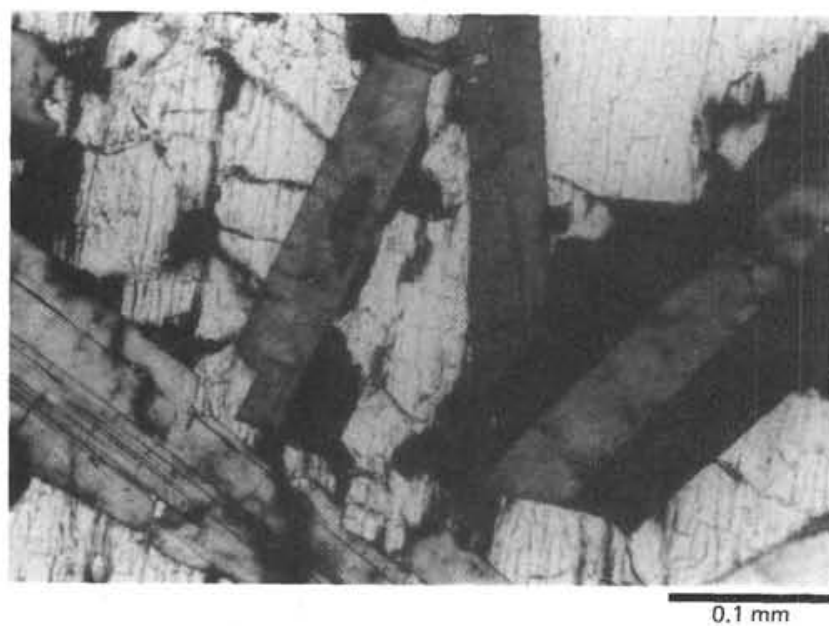

Figure 1. Photomicrograph of thin section from Site 368, Core 60, core-catcher sample, crossed nichols. Sample is $180 \mathrm{~cm}$ from top of thick intrusive unit and exhibits near-gabbroic textures with several euhedral plagioclase crystals poikilitically enclosed by a much larger optically continuous clinopyroxene grain.

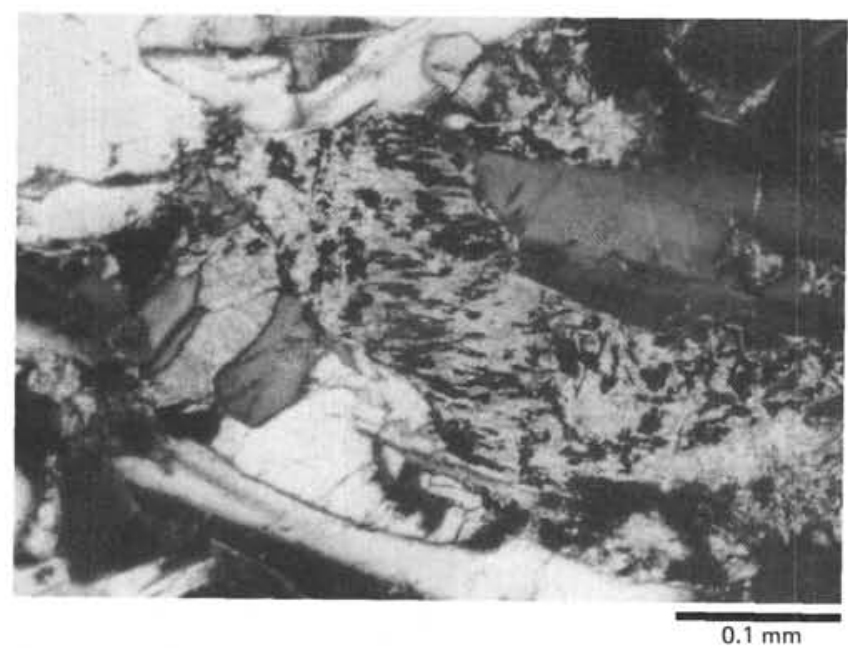

Figure 2. Photomicrograph of thin section from Site 368, Core 60, core-catcher sample, crossed nichols, same sample as in Figure 1. This view shows an intersertal patch of secondary calcite (center left, with high relief), and clays with subparallel strings of pyrite.

in the compilation of data. In Section 368-61-4, the total is also reduced by the presence of sulfur in pyrite, which amounts to as much as $1 \%-2 \%$ in the modes of thin sections taken from nearby intervals. A very fresh East Pacific Rise basalt (PL-2D-3 from the rise crest near $3^{\circ} \mathrm{S}$ latitude dredged on SIO's Pleiades Expedition and donated by Peter Lonsdale) was prepared and run at the same time as the Leg 41 basalts. Its total of $99.71 \%$ is representative of the total oxides, the Leg 41 basalts should have had if they were fresh, and without authigenic pyrite.

The two samples from Site 367 must contain at least $4 \%-6 \%$ combined water plus $\mathrm{CO}_{2}$, since authigenic pyrite is minor or absent. The samples before powdering were free of carbonate-filled vesicles; thus the main alteration effect is one of hydration. Hart (1971) demonstrated that pristine $\mathrm{K}, \mathrm{Rb}, \mathrm{Cs}$, and $\mathrm{Ba}$ contents cannot be determined in mid-ocean ridge basalts in which combined water exceeds $2 \%$; all will have been markedly increased by interaction with seawater. Therefore the $\mathrm{K}$ and $\mathrm{Ba}$ contents of the Site 367 basalts, low as they are, almost certainly have been increased by interaction with seawater. The low $\mathrm{K}$ and $\mathrm{Ba}$, coupled with low $\mathrm{TiO}_{2}$ and $\mathrm{Zr}$ (two elements relatively inert to alteration), and the high hypersthene in the reduced norm, verify that the Site 367 basalts are indeed oceanic tholeiites. The Site 367 basalts have somewhat higher $\mathrm{TiO}_{2}$ than normal Mid-Atlantic Ridge basalts $\left(1.7 \%\right.$ versus $1.1 \%$ at $37^{\circ} \mathrm{N}$, Bougault and Hekinian, 1974 , versus $1.5 \%-1.6 \%$ at DSDP Site 395 at $22^{\circ} \mathrm{N}$, Leg 45 Shipboard Party, 1976), and higher $\mathrm{FeO}^{*}$. Of the two samples analyzed, 367-39-2 appears to be most fractionated. Both samples have high $\mathrm{P}_{2} \mathrm{O}_{5}$, a good indicator of extensive fractionation (Anderson and Greenland, 1969; Clague and Bunch, 1976). Since the high $\mathrm{TiO}_{2}$ and $\mathrm{P}_{2} \mathrm{O}_{5}$ are coupled with a marked $\mathrm{FeO}^{*}$ and $\mathrm{V}$ enrichment, and since the rocks contain relatively low $\mathrm{MgO}$, as in typical mid-ocean ridge ferrobasalts, it appears that the Site 367 basalts are fairly fractionated derivatives of more primitive parents with lower $\mathrm{TiO}_{2}$ contents. $\mathrm{MnO}, \mathrm{Cu}$, and $\mathrm{Zn}$ are unusually high, possibly because ferromanganese oxides may have been deposited in fine cracks throughout the basalt.

The sample analyzed from Site 368 reported in Table 2 is also tholeiitic. It has lower $\mathrm{TiO}_{2}$ than most midocean ridge basalts and is hypersthene normative. Four other samples from Site 368 have been partially analyzed, all more altered than Section 368-61-4. These have similar low $\mathrm{TiO}_{2}(0.81 \%-1.17 \%)$ and $\mathrm{Zr}(<70 \mathrm{ppm})$ and even low $\mathrm{K}_{2} \mathrm{O}(0.35 \%-0.51 \%)$ although they must contain several per cent combined water. In four of the five samples, $\mathrm{Rb}$ ranges from 4 to $7 \mathrm{ppm}$, but in the most altered sample (from the base of the thick sill), it is $70 \mathrm{ppm} . \mathrm{CaCO}_{3}$ is over $5 \%$ in this sample. $\mathrm{Sr}$ is enriched in all samples primarily because of the secondary calcite, which probably has a high $\mathrm{SrCO}_{3}$ content. $\mathrm{Cr}$ is high, but chrome spinel was not seen in thin sections.

The analysis reported in Table 2, from Section 368$61-4$, was on a sample taken within centimeters of a sample reported by Duncan and Jackson (this volume) to have concordant $\mathrm{K} / \mathrm{Ar}$ whole-rock and ${ }^{39} \mathrm{Ar} /{ }^{40} \mathrm{Ar}$ incremental heating ages. The concordant ages testify to the freshness of the dated sample. The low total of Section 368-61-4 is seemingly inconsistent with the freshness implied by the concordant ages. The low total is, however, consistent with the modal proportion of altered intersertal glass, calcite, and pyrite observed in thin sections from the coarser grained portions of the intrusive, but these may not necessarily be representative of the freshness of the sample dated by Duncan and Jackson. It is possible, for example, that the sample whose analysis is reported here was closer to a crack around which alteration is more intense than in the radiometrically dated sample. A major question is whether the abundant pyrite and calcite in the interior of the thick sill are authigenic minerals precipitated from pore fluids permeating the rock after crystal- 
TABLE 2

Chemical Analyses of Basalts from Sites 367 and 368, DSDP Leg 41, Drilled Near the Cape Verde Islands (major elements in weight \%)

\begin{tabular}{|c|c|c|c|c|c|c|c|c|c|c|}
\hline & \multicolumn{2}{|c|}{1} & \multicolumn{3}{|c|}{2} & \multicolumn{2}{|c|}{3} & $4^{a}$ & $5^{b}$ & $6^{\mathrm{c}}$ \\
\hline Sample & \multicolumn{2}{|c|}{$\begin{array}{l}367-38-3, \\
50-51 \mathrm{~cm}\end{array}$} & \multicolumn{3}{|c|}{$\begin{array}{l}367-39-2 \\
70-71 \mathrm{~cm}\end{array}$} & \multicolumn{2}{|c|}{$\begin{array}{l}368-61-4 \\
79-81 \mathrm{~cm}\end{array}$} & $\begin{array}{c}113 \\
\text { Limburgites, } \\
\text { Basanites }\end{array}$ & $\begin{array}{c}55 \\
\text { Basan- } \\
\text { ites }\end{array}$ & TH \\
\hline $\mathrm{SiO}_{2}$ & 45.50 & 47.87 & & 6.20 & 49.27 & 47.96 & 50.10 & 43.39 & 44.19 & 50.40 \\
\hline $\mathrm{Al}_{2} \mathrm{O}_{3}$ & 14.82 & 15.59 & & 4.42 & 15.37 & 14.08 & 14.71 & 13.15 & 14.66 & 14.49 \\
\hline $\mathrm{FeO}^{*}$ & 12.99 & 13.67 & & 2.76 & 13.61 & 10.85 & 11.34 & 11.96 & 13.30 & 10.98 \\
\hline $\mathrm{MgO}$ & 7.57 & 7.96 & & 6.00 & 6.40 & 7.33 & 7.66 & 9.60 & 6.70 & 8.08 \\
\hline $\mathrm{CaO}$ & 9.49 & 9.98 & & 9.63 & 10.27 & 11.65 & 12.17 & 12.81 & 12.31 & 11.50 \\
\hline $\mathrm{Na}_{2} \mathrm{O}$ & 2.16 & 2.27 & & 2.19 & 2.34 & 2.48 & 2.59 & 3.17 & 3.79 & 2.83 \\
\hline $\mathrm{K}_{2} \mathrm{O}$ & 0.17 & 0.18 & & 0.26 & 0.28 & 0.38 & 0.40 & 1.08 & 1.33 & 0.12 \\
\hline $\mathrm{TiO}_{2}$ & 1.70 & 1.79 & & 1.68 & 1.79 & 0.98 & 1.02 & 3.86 & 4.08 & 1.30 \\
\hline $\mathrm{P}_{2} \mathrm{O}_{5}$ & 0.25 & 0.26 & & 0.25 & 0.26 & 0.18 & 0.19 & 0.81 & 0.91 & 0.10 \\
\hline $\mathrm{MnO}$ & 0.40 & 0.42 & & 0.38 & 0.41 & 0.17 & 0.19 & 0.18 & 0.20 & 0.19 \\
\hline $\mathrm{CO}_{2}$ & - & - & & - & - & 0.02 & - & - & - & - \\
\hline $\mathrm{CaO}^{\mathrm{a}}$ & - & - & & - & - & 0.03 & - & - & - & - \\
\hline Total & 95.05 & & & 3.77 & & 5.77 & & & & \\
\hline \multicolumn{11}{|c|}{ C. I.P. W. } \\
\hline Norms & $\mathrm{N}$ & 1.5 & & $\mathrm{~N}$ & 1.5 & $\mathrm{~N}$ & 1.5 & & & \\
\hline OR & 1.06 & 1.06 & & 1.64 & 1.64 & 2.35 & 2.34 & & & \\
\hline $\mathrm{AB}$ & 19.23 & 19.20 & & 9.76 & 19.74 & 21.92 & 21.89 & & & \\
\hline AN & 31.82 & 31.77 & & 0.66 & 30.62 & 27.33 & 27.29 & & & \\
\hline WO & 6.68 & 6.67 & & 7.75 & 7.73 & 13.35 & 13.33 & & & \\
\hline EN & 9.98 & 12.58 & & 1.87 & 14.66 & 8.11 & 10.72 & & & \\
\hline FS & 11.54 & 12.03 & & 6.98 & 17.27 & 8.27 & 8.73 & & & \\
\hline FO & 6.91 & 5.07 & & 2.85 & .88 & 7.68 & 5.83 & & & \\
\hline FA & 8.80 & 5.34 & & 4.49 & 1.14 & 8.63 & 5.23 & & & \\
\hline MT & - & 2.29 & & - & 2.32 & - & 2.27 & & & \\
\hline IL & 3.40 & 3.39 & & 3.40 & 3.40 & 1.94 & 1.94 & & & \\
\hline $\mathrm{AP}$ & 0.62 & 0.62 & & 0.63 & 0.63 & 0.45 & 0.45 & & & \\
\hline DI & 13.30 & 13.20 & & 5.53 & 15.41 & 26.46 & 26.23 & & & \\
\hline HY & 14.90 & 18.09 & & 1.06 & 24.25 & 3.26 & 6.55 & & & \\
\hline OL & 15.70 & 10.41 & & 7.33 & 2.02 & 16.31 & 11.06 & & & \\
\hline Q & - & - & & - & - & - & - & & & \\
\hline \multicolumn{11}{|c|}{$\begin{array}{l}\text { Trace } \\
\text { Elements (ppm) }\end{array}$} \\
\hline $\mathrm{Rb}$ & & $<2$ & $<2$ & 6 & & & & & & \\
\hline $\mathrm{Sr}$ & & 155 & 120 & 205 & & & & & & \\
\hline $\mathrm{Ba}$ & & 30 & 100 & 280 & & & & & & \\
\hline $\mathrm{Zr}$ & & 101 & 106 & 62 & & & & & & \\
\hline $\mathrm{Cu}$ & & 183 & 202 & 70 & & & & & & \\
\hline $\mathrm{Zn}$ & & 220 & 264 & 325 & & & & & & \\
\hline $\mathrm{Cr}$ & & 91 & 90 & 485 & & & & & & \\
\hline $\mathrm{Ni}$ & & 64 & 66 & 128 & & & & & & \\
\hline V & & 390 & 375 & 245 & & & & & & \\
\hline
\end{tabular}

Note: (1) Analyses: first column for each sample has all iron as $\mathrm{FeO}\left(\mathrm{FeO}^{*}\right)$, and gives the total as determined. The second column gives the analyses dry, reduced, $\mathrm{CaCO}_{3}$-free (if applicable) and normalized to $100 \%$. The trace element data is in ppm. (2) Norms: first column under each analysis gives the norms dry, reduced, and normalized to $100 \%$. The second column is the same, except with $1.5 \% \mathrm{Fe}_{2} \mathrm{O}_{3}$. The dry reduced norms are labelled $\mathrm{N}$, the partially oxidized norms 1.5 . (3) Methods and Precision of trace element analyses are: Rb - Atomic absorption (AA) $\pm 3 \mathrm{ppm} ; \mathrm{Sr}$ $\mathrm{AA} \pm 10 \mathrm{ppm} ; \mathrm{BA}-\mathrm{X}$-ray fluorescence $(\mathrm{XRF}) \pm 20 \mathrm{ppm} ; \mathrm{Zr}-\mathrm{XRF} \pm 5 \mathrm{ppm} ; \mathrm{Cu}-\mathrm{AA} \pm 2 \mathrm{ppm}$; $\mathrm{Zn}-\mathrm{AA} \pm 5 \mathrm{ppm} ; \mathrm{Cr}-\mathrm{AA} \pm 5 \mathrm{ppm} ; \mathrm{Ni}-\mathrm{AA} \pm 10 \mathrm{ppm} ; \mathrm{V}-\mathrm{AA} \pm 10 \mathrm{ppm}$.(4) Average of 113 limburgites and basanites, Cape Verde Islands; Gunn and Watkins, 1976. (5) Average of 55 basanites, Cape Verde Islands; Gunn and Watkins, 1976. (6) Average of two basalts from Ribeira do Morro, Maio, Cape Verde Islands; DePaepe et al., 1974.

${ }^{\mathrm{a}} \mathrm{CaO}$ in $\mathrm{CaO}_{3}$. 
lization, or whether they are primarily late-stage magmatic or deuteric minerals formed from volatile constituents originally dissolved in the magma. These constituents presumably could have been ingested into the intruding magma from the carbon- and sulfur-rich sediments during intrusion, then been dissolved, and eventually precipitated in the form of late-stage minerals. If the minerals are authigenic, and alteration occurred in an essentially open system, concordant ages should not have resulted. However, if the magma became volatile-charged as a result of assimilation, then the water, carbonate, and sulfur in the rocks would not necessarily reflect alteration affecting the K-Ar system. Texturally, pyrite and carbonate do not seem preferentially concentrated in more altered zones next to cracks, as might be expected if they were carried into the rock after cooling by pore fluids. On the other hand, $\mathrm{K}_{2} \mathrm{O}$ and $\mathrm{Rb}$ seem fairly constant even in the most altered coarse-grained samples for which partial analyses have been made. Little is known about the mobility of these elements, or of the stability of the KAr system, during alteration under reducing conditions. Other basalts from the oceans dated by incremental heating ${ }^{39} \mathrm{Ar} /{ }^{40} \mathrm{Ar}$ techniques typically have experienced oxidative rather than reducing alteration conditions, and have incorporated much $\mathrm{K}$ from seawater, destroying the possibility of obtaining reliable dates. This obviously did not happen in the basalts dated at Site 368 .

$\mathrm{Ba}$ is enriched relative to $\mathrm{TiO}_{2}$ and $\mathrm{Zr}$ in Section 368$61-4$, which may also be explained by assimilation of materials from the surrounding sediments. Barite rosettes are reported to be abundant in the black carbonaceous sediments intruded by the basalts (Chapter 4 , this volume), and their assimilation may have accompanied assimilation of sulfur and carbonate as previously described. Strong (1972) reports anomalously high $\mathrm{Ba}$ contents in alkalic basalts and nephelinites from the Comores Islands off East Africa. These basalts include sandstone xenoliths from the sediments beneath the Comores volcanic pile. They almost certainly include black shales of Cretaceous age formed in the small, restricted ocean basin which existed shortly after Madagascar separated from the eastern coast of Africa. Carbonaceous sediments of Neocomian age were drilled at DSDP Site 249 on the Mozambique Plateau (Simpson, Schlich, et al., 1974). Similar sediments of the same age should underlie the western continental margin of Madagascar, following the hypothesis of Flores (1970) that Madagascar moved away from Mozambique from the Early Jurassic to the Turonian. Strong (1972) interprets the high $\mathrm{Ba}$ in the Comores lavas to be a consequence of the residual behavior of amphibole during melting of the lavas. There is, however, no systematic variation in $\mathrm{k} / \mathrm{Ba}$, $\mathrm{Rb} / \mathrm{Ba}$, or $\mathrm{Sr} / \mathrm{Ba}$ in Comores lavas reported by Strong that would support his argument. $\mathrm{Ba}$ is high and effectively constant through wide ranges in the variation of the other elements. Assimilation of $\mathrm{Ba}$ from sediments is a plausible alternative, given the sandstone xenoliths.

Apart from the $\mathrm{Ba}$, there is no question about the tholeiitic character of Section 368-61-4. The low $\mathrm{TiO}_{2}$ and $\mathrm{Zr}$ are especially indicative. The only island edifice tholeiitic basalts with $\mathrm{TiO}_{2}$ as low are those of Kohala volcano, Hawaii (Macdonald, 1968). The concordant radiometric ages of the Site 368 basalts reported by Duncan and Jackson (this volume) leave little doubt that the basalts represent the earliest stages of Cape Verde Island volcanism, 19 million years ago. The exposed Cape Verde Islands are, so far as is known, entirely composed of highly undersaturated mafic lavas and associated differentiates, including carbonatites (Dillon and Sougy, 1974; Part, 1950; Assunçao et al., 1968; Klerkx et al., 1974; Gunn and Watkins, 1976). Representative average analyses from Gunn and Watkins are included in Table 2 for comparison. De Paepe et al. (1974), however, report an Early Cretaceous upfaulted basement complex exposed on the Cape Verde Island of Maio. This basement complex has the structure and composition of oceanic crust. Section 368-61-4 is very close in composition to rocks from this basement complex (De Paepe et al., 1974), one of which is listed in Table 2 for comparison. Were it not for the intrusive petrographic and contact relations of the Site 368 basalts, and the concordant Miocene radiometric ages, one could well believe that the Site 368 basalts are part of the oceanic crust basement complex (erupted at the Mid-Atlantic Ridge) beneath the Cape Verde Islands. They are the right composition, and the sediments they intrude are the right age (Turonian-Albian).

Instead, we are left with the intriguing and important conclusion that the first stages of Cape Verde Island volcanism were chemically very little different from the volcanism along the Mid-Atlantic Ridge, and that the result of 19 million years of Cape Verde volcanism has been an evolution to compositions as radically different from oceanic tholeiites as any proposed for mantle derivation (cf. Klerkx et al., 1974). This evolution is even more remarkable if all Cape Verde volcanism comes from a geochemically distinct mantle plume (Morgan, 1972).

The comments in this paper about the possible effects of assimilation and alteration on the chemistry of the Site 368 basalts suggest caution in the use of any further geochemical or isotopic data to define the composition of the mantle source of these basalts. The effects of assimilation and alteration must first be assessed quantitatively before the pristine characteristics of the basalts will emerge. The high $\mathrm{Ba}$ and the somewhat high $\mathrm{K}_{2} \mathrm{O}$ of the Site 368 basalts may stem partly from primary mantle-derived characteristics, but it is likely that even minor assimilation of the surrounding sediments has swamped the original $\mathrm{K}_{2} \mathrm{O}$ and $\mathrm{Ba}$ abundances. Neglecting possible assimilation effects, the differences between the Site 368 basalts and typical oceanic tholeiites are subtle indeed.

\section{ACKNOWLEDGMENTS}

My thanks to J.V. Gardner and E.D. Jackson for supplying samples and/or thin sections, and to E.D. Jackson and R.J. Kirkpatrick for constructive criticism of the manuscript. R. Meyer, C. Nelson, and R.T. LaBorde assisted with the analyses. W. Brennan made several thin sections and polished others. 


\section{REFERENCES}

Anderson, A.T. and Greenland, L.P., 1969. Phosphorus fractionation diagram as a quantitative indicator of crystallization differentiation of basaltic liquids: Geochim. Cosmochim. Acta, v. 33, p. 493-505.

Assunçao, C.T. de, Machado, F., and Serraheiro, A., 1968. New investigations on the geology and volcanism of the Cape Verde Islands: Twenty-third Int. Geol. Congr., v. 2, p. 9-16.

Bougault, H. and Hekinian, R., 1974. Rift Valley in the Atlantic Ocean near $36^{\circ} 50^{\prime} \mathrm{N}$ : petrology and geochemistry of basaltic rocks: Earth Planet. Sci. Lett., v. 24, p. 249261.

Clague, D.A., 1974. The Hawaiian-Emperor Seamount Chain: its origin, petrology, and implications for plate tectonics: Unpublished Ph.D. Dissertation, University of California, San Diego.

Clague, D.A. and Bunch, T.E., 1976. Formation of ferrobasalt at East Pacific mid-ocean spreading centers: J. Geophys. Res., v. 81 , p. $4247-4256$.

De Paepe, P., Klerkx, J., Hertogen, J., and Plinke, P., 1974. Oceanic tholeiites on the Cape Verde Islands: petrochemical and geochemical evidence: Earth Planet. Sci. Lett., v. 22, p. 347-354.

Dillon, W.P. and Sougy, J.M.A., 1974. Geology of West Africa and the Canary and Cape Verde Islands. In Nairn, A.E.M. and Stehli, F.G. (Eds.), The ocean basins and margins, Volume 2: the North Atlantic: New York (Plenum Press), p. 315-390.

Flores, G., 1970. Suggested origin of the Mozambique Channel: Geol. Soc. S. Africa Trans., v. 73, p. 553-562.

Gunn, B.M. and Watkins, N.D., 1976. Geochemistry of the Cape Verde Islands and Fernando de Noronha: Geol. Soc. Am. Bull., v. 87, p. 1089-1100.

Hart, S.R., 1971. Rb, Cs, Sr, and Ba contents, and Sr isotopic ratios of ocean floor basalts: Phil. Trans. Roy. Soc. London, Ser. A., v. 268, p. 573-587.

Klerkx, J., Deutsch, S., and De Paepe, P., 1974. Rubidium, strontium, and strontium isotopic composition of strongly alkalic basaltic rocks from the Cape Verde Islands: Contrib. Mineral. Petrol., v. 45, p. 107-118.

Leg 45 Shipboard Party, 1976. Challenger drills on Leg 45 along the Mid-Atlantic Ridge: Geotimes, April, p. 20-23.

Macdonald, G.A., 1968. Composition and origin of Hawaiian lavas: Geol. Soc. Am. Mem. 116, p. 821-837.

Morgan, W.J., 1972. Deep mantle convection plumes and plate motions: Am. Assoc. Petrol. Geol. Bull., v. 56, p. 203-213.

Part, G.M., 1950. Volcanic rocks from the Cape Verde Islands: British Mus. Nat. History Bull., v. 1, p. 1-27.

Simpson, E.S.W. and Schlich, R., et al., 1974. Initial Reports of the Deep Sea Drilling Project, Volume 25: Washington (U.S. Government Printing Office).

Strong, D.F., 1972. The petrology of the lavas of Grand Comore: J. Petrol., v. 13, p. 181-217. 